\title{
LANDSCAPE 100: HOW FINLAND, ESTONIA AND LATVIA USED LANDSCAPE IN CELEBRATING THEIR CENTENARY ANNIVERSARIES
}

\author{
Anu Printsmann ${ }^{1}$, Hannu Linkola ${ }^{2}$, Anita Zariņa ${ }^{3}$, Margarita Vološina ${ }^{4}$, \\ Maunu Häyrynen ${ }^{5}$, Hannes Palang ${ }^{6}$
}

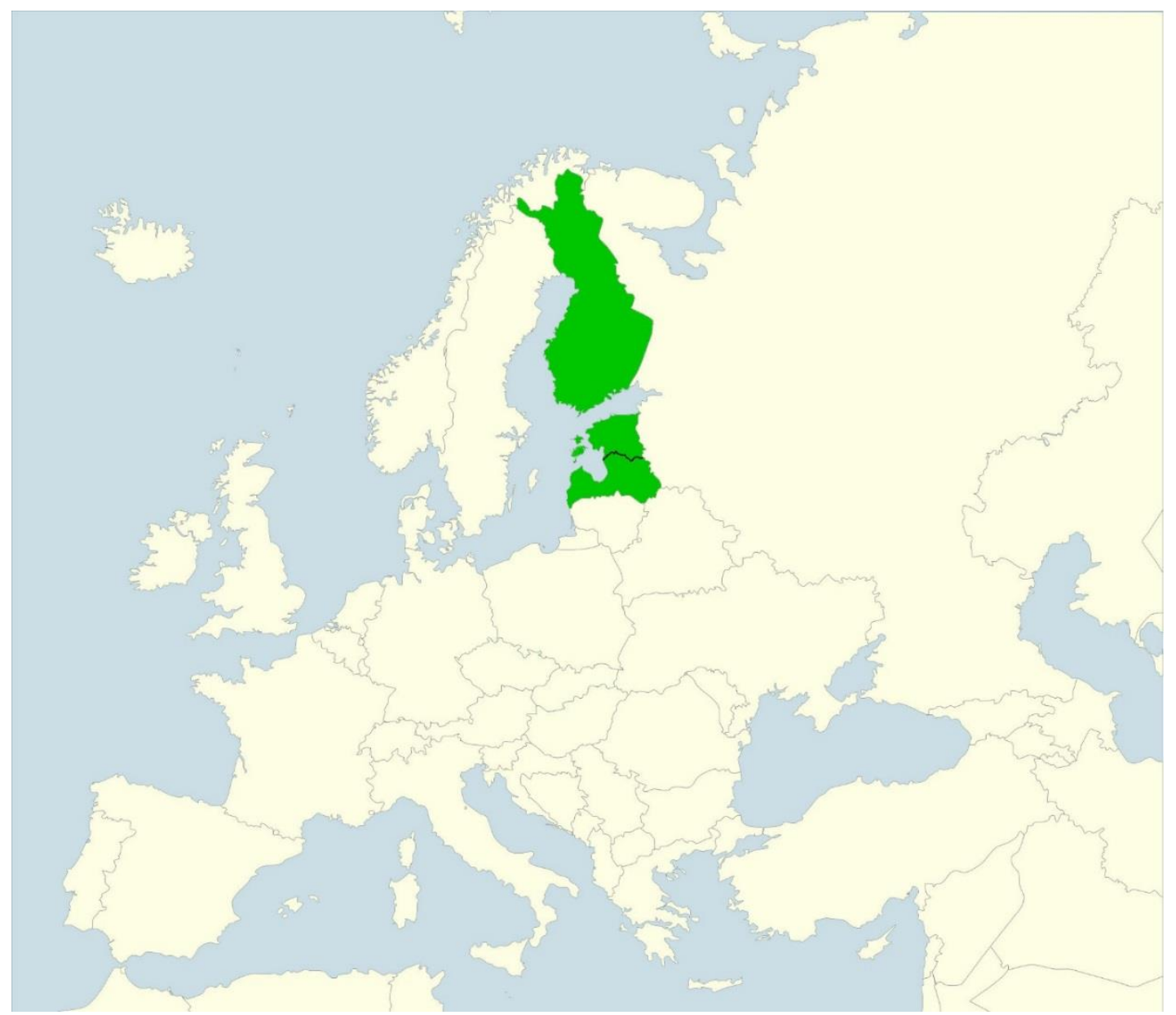

\footnotetext{
${ }^{1}$ Anu Printsmann, School of Humanities, Tallinn University, e-mail: anu.printsmann@tlu.ee

2 Hannu Linkola, Degree Programme in Cultural Production and Landscape Studies, University of Turku, e-mail: hjlink@utu.fi; ORCID: 0000-0002-7398-5352

${ }^{3}$ Anita Zariņa, Faculty of Geography and Earth Sciences, University of Latvia Riga, e-mail: anita.zarina@lu.Iv

${ }^{4}$ Margarita Vološina, Faculty of Geography and Earth Sciences, University of Latvia Riga; ORCID: 0000-0001-89223558

${ }^{5}$ Maunu Häyrynen, Degree Programme in Cultural Production and Landscape Studies, University of Turku, e-mail: mauhay@utu.fi

${ }^{6}$ Hannes Palang, School of Humanities, Tallinn University, e-mail: hannes.palang@tlu.ee; ORCID: 0000-0002-19812071
} 


\begin{abstract}
In the aftermath of what was then the Great War several European countries like Finland, Estonia and Latvia gained independence, marking their centenary jubilees 2017-2018. This paper observes how landscapes were used in anniversary celebrations and what historical themes were foregrounded and which omitted, revealing how collective historical commemoration in landscape enacts within national identity framework depending also on how landscape is understood in each respective country.
\end{abstract}

Key words: national landscapes, collective memory, heritage, past, practices, imagery

\begin{abstract}
Abstrakti: Ensimmäisen maailmansodan seurauksena moni eurooppalainen valtio, kuten Suomi, Viro ja Latvia, itsenäistyi. Samat valtiot viettivät itsenäisyytensä satavuotisjuhlaa vuosina 2017-2018. Tässä artikkelissa havainnoimme, miten maisemia käytettiin satavuotisjuhlallisuuksissa, mitä teemoja nostettiin näkyville ja mitä sivuutettiin. Tutkimuksemme osoittaa miten maisemaan linkittyvä kollektiivinen historiallinen muistaminen toimii kansallisen identiteetin viitekehyksessä, ja miten se on samalla riippuvainen siitä, miten maisema ymmärretään kussakin kohdemaassamme.
\end{abstract}

Asiasanat: kansallismaisemat, kollektiivinen muisti, kulttuuriperintö, menneisyys, käytännöt, kuvasto

Teesid: Soome, Eesti ja Läti saavutasid iseseisvuse toona niinimetatud Suure ilmasõja järeltuules, tähistades oma sajandaid juubeleid aastatel 2017-2018. See artikkel vaatleb, kuidas maastikku nendes pidustustes kasutati, milliseid ajaloolisi teemasid tõsteti esile ning mis jäi üldse mainimata, paljastades, kuidas kollektiivne ajalooline mälestamine maastikus toimib rahvusliku identiteedi raamistikus, sõltudes ka sellest, kuidas maastiku igal maal mõistetakse.

Võtmesõnad: rahvusmaastikud, kollektiivne mälu, pärand, minevik, praktikad, pildilisus

\begin{abstract}
Abstrakts: Somija, Igaunija un Latvija 2017.-2018. gadā svin savas 1. pasaules kara rezultātā iegūtās valstiskās neatkarības simtgades jubilejas. Šajā rakstā tiek aplūkots ainavas lietojums valstu simtgades svinībās: kuras no ar ainavu saistītām vēsturiskām un mūsdienu tematikām atrodas dažādu pasākumu un projektu priekšplānā un kuras netiek celtas dienasgaismā. Raksts tādējādi atspoguḷo tos diskursus, kurus katrā no valstīm veido izpratne par kolektīvo ainavu valstu nacionālās identitātes veidošanā un uzturēšanā.
\end{abstract}

Atslēgas vārdi: nacionālās ainavas, kolektīvā atmiņa, mantojums, pagātne, prakses, tēlkopa

\title{
1. Introduction
}

The year 2018 marked the hundredth anniversary of the end of the First World War. It also meant that many countries like Finland, Estonia and Latvia which used that turbulence to become independent, celebrated their $100^{\text {th }}$ birthdays. The national centenaries were widely commemorated, and landscape played an important part there. Indeed, as Peter Burke (1989) concluded, that space (and consequently landscape) is a vehicle of social memory, albeit both tend to change over the course of time.

The significant role of landscapes in the festivities is not a surprise, as Jay Appleton writes (1996) on the back of his book cover, 'Landscape is a kind of backcloth to the whole stage of human activity'. It is a by-product of human practices as we very rarely set out to create landscapes. So on the one hand, landscape is always present in whatever we do. On the other hand, following 
David Lowenthal's (it says 1985 in the list of references) idea of landscape as a recorder, we see that landscape registers (the results of) our activities and enables us to learn from the past. It functions as a storage and medium of national memory (see Cosgrove, 1998). When the nation celebrates its history, the record will be played once again.

Landscape is by no way an innocent outsider, and its archival capabilities are not all-inclusive (Brockmeier, 2010). Jubilees are occasions to reminisce, retrospectively and retrogressively (see Baker, 1968) inspect the past and adjust the hindsight. National centenaries confirm the dominant narratives and at least the more obvious symbolic landscapes are likely to be paraded in the celebrations (Burke, 1989; Schama, 1996). This also provides the opportunity to look back at these decisions and overlooked themes of national landscapes summing up the ways landscapes are used in our everyday activities.

We first give a brief overview of history underlining some commonalities elucidating commemorative choices in the theoretical part. Similar are state-led conventions of celebrating the anniversaries but for each specific country, we try to follow in which sense landscape was understood in the public discourse, which themes were used in the festivities, which questions caused conflicts and which topics were ignored altogether. We discuss similarities and differences and draw some conclusions on dynamics between nationally charged (collective) and people's mundane understandings of landscapes.

\section{A brief comparative history}

The comparative aspect of the study is particularly intriguing, as Finland, Estonia and Latvia share common reference points in history, and yet have diverging development trajectories, the major difference being that Finland has remained independent for 100 years, while Estonia and Latvia were half of that time under the Soviet regime. A comparative study also helps us to counteract methodological nationalism, warned about by Eric Hobsbawm (1983: 13-14).

By the end of the $19^{\text {th }}$ century, all three countries had become parts of the Russian Empire Finland as a separate autonomous Grand Duchy, while Estonia and Latvia were divided into three provinces, Estland, Livland and Courland, which also had some privileges, as compared to 'regular' provinces. Throughout the period, the Nordic orientation in Finland was strong, and its early nationalist movement and building of national institutions explicitly followed Scandinavian models. This was helped by the fact that Swedish remained an official language besides Finnish.

Tab 1. War and peace time layers for Finland, Estonia and Latvia.

\begin{tabular}{|c|c|c|c|}
\hline & Finland & Estonia & Latvia \\
\hline $\begin{array}{l}\text { Independence } \\
\text { declared }\end{array}$ & 6.12 .1917 & 24.2.1918 & 18.11.1918 \\
\hline Independence & Civil War 1.-5.1918 & $11.1918-2.1920$ & $11.1918-8.1920$ \\
\hline Independence & Independent & Independent & Independent \\
\hline WWII & $\begin{array}{l}\text { Winter War with the } \\
\text { USSR 11.1939-3.1940 } \\
\text { Continuation War with } \\
\text { the USSR 6.1941-9.1944 }\end{array}$ & $\begin{array}{l}\text { Soviet occupation } \\
6.1940-7.1941 \\
\text { Nazi occupation } \\
7.1941-10.1944\end{array}$ & $\begin{array}{l}\text { Soviet occupation } \\
6.1940-7.1941 \\
\text { Nazi occupation } \\
7.1941-4.1945\end{array}$ \\
\hline Post-WWII & Independent & $\begin{array}{l}\text { Part of the USSR 1944- } \\
1991\end{array}$ & $\begin{array}{l}\text { Part of the USSR 1944- } \\
1991\end{array}$ \\
\hline Independence & & Independence 8.1991 & Independence 8.1991 \\
\hline European Union & 1.1995 & 5.2004 & 5.2004 \\
\hline
\end{tabular}


However, the Russification policy of the Empire in the late $19^{\text {th }}$ century caused also cultural and societal changes, alongside industrial ones. As an outcome, all three used the turmoil of WWI and the Russian revolution to gain independence (table 1). But to confirm the independence, all three had to go through war. In Finland, this was mostly a Civil War that clearly divided the country and caused a lot of trauma still to be healed. In Estonia and Latvia, it was mostly a struggle against the Russians/Soviets and the Germans (see chronology in Parrot, 2002). From 1920 onwards, the countries could start building up, and landscapes were definitely helpful in creating the new national identities (Käyhkö et al., 2004; Peil et al., 2004; Zariña and Krumberga, 2018). Among the first significant societal changes were the land reforms and the gradual change of dominating language, from Swedish to Finnish and from German to Estonian and Latvian.

In 1939, all three faced ultimatums from the USSR. Finland did not agree to host Soviet military bases and this refusal resulted in the Winter War that was followed by the Continuation War, but Finland remained independent also after the WWII. Estonia and Latvia, at the same time, allowed the bases, and got incorporated into the USSR, suffered the Nazi occupation and remained occupied by the USSR until 1991, when their independence was restored. Finland joined the European Union in 1995, Estonia and Latvia followed in the next wave in 2004. Landscapewise (table 2), such history means Estonia and Latvia have got a specific layer of Soviet landscapes (see Palang, 2010; Palang et al., 2006; Zarina, 2010, 2013) that Finland lacks.

Tab 2. Some comparative figures for the social landscape of the three countries to set the context.

\begin{tabular}{|l|l|l|l|}
\hline & Finland & Estonia & Latvia \\
\hline Area $\left(\mathrm{km}^{2}\right)$ before WWII & 383,000 & 47,000 & 65,800 \\
\hline Area $\left(\mathrm{km}^{2}\right)$ after WWII & 338,424 & 45,339 & 64,589 \\
\hline Population 1917/1918 & $3,134,300$ & $\begin{array}{l}1897: 958,351 \\
1922: 1,107,059\end{array}$ & $\begin{array}{l}1897: 1,929,387 \\
1925: 1,844,805\end{array}$ \\
\hline Population 1991 & $5,029,002$ & $\begin{array}{l}1989: 1,565,662 \\
2000: 1,370,052\end{array}$ & $1989: 2,680,029$ \\
& $2000: 2,381,715$ \\
\hline Population 1.2018 & $5,513,130$ & $1,319,133$ & $1,934,379$ \\
\hline Ethnic groups 1.2018 & $\begin{array}{l}\text { Finnish speakers 88\% } \\
\text { Swedish speakers 5\% } \\
\text { Sámi speakers 0.04\% } \\
\text { Other languages 7\% } \\
\text { (biggest groups } \\
\text { Russian and Estonian) }\end{array}$ & $\begin{array}{l}\text { Estonians 69\% } \\
\text { Other 5\% }\end{array}$ & $\begin{array}{l}\text { Unknown 1\% } \\
\text { Latvians 62\% } \\
\text { Russians 25\% } \\
\text { Other 0.5\% } \\
\text { Unknown 2\% }\end{array}$ \\
\hline Citizenship 1.2017 & $\begin{array}{l}\text { Finnish 95\% } \\
\text { Other than Finnish } \\
\text { (e.g., Russian, } \\
\text { Estonian, Iraqi) } 5 \% \\
\text { New Finnish (e.g., } \\
\text { Russian, Somali, Iraqi) } \\
\text { 0.2\% } \\
\text { With double } \\
\text { citizenship (e.g., } \\
\text { Russian, Swedish, } \\
\text { Somali) 2\% }\end{array}$ & $\begin{array}{l}\text { Estonian 85\% } \\
\text { Russian 7\% } \\
\text { Not defined 6\% } \\
\text { Others (e.g., Ukraine) } \\
\text { Other 1\% } \\
\text { Unknown 0\% }\end{array}$ & $\begin{array}{l}\text { Latvian 86\% } \\
\text { Russian 2\% } \\
\text { Non-citizens of Latvia } \\
\text { Others (e.g., } \\
\text { Lithuania, Ukraine, } \\
\text { Belarus) <1\% }\end{array}$ \\
\hline
\end{tabular}

(data: ec.europa.eu/eurostat, https://www.stat.ee/dokumendid/62869,

http://andmebaas.stat.ee/Index.aspx?lang=et\&DataSetCode=RV0222U,

http://andmebaas.stat.ee/Index.aspx?lang=et\&DataSetCode=RV069, https://www.csb.gov.Iv/en/statistics/statistics-by-

theme/population/number-and-change/search-in-theme/301-demography-2018,

https://data1.csb.gov.Iv/pxweb/Iv/iedz/iedz_iedzrakst/IRG140.px/table/tableViewLayout1)

https://www.stat.fi/til/kans/2017/kans 2017 2018-06-14 tie 001 fi.html,

https://www.stat.fi/til/vaerak/2018/vaerak_2018_2019-03-29_tau_001_fi.html

https://www.stat.fi/tup/suomigo/joulukuu. $\bar{h}$ tml). 


\section{Landscape and commemorative politics}

While landscape affects our understanding of spatial belonging, manifests our interaction with the environment, and records history, it is also an essential social category (Palang et al., 2011). Landscape is, for example, a crucial element of national identity politics (table 3), and seen from this perspective, it is a political and symbolic entity that brings space and body together in order to create an illusion of an organic togetherness between nation and national territory (Mels, 2003: 382). Hence, it is also a forum through which the national space is being classified regionally, and hierarchies between places and people are negotiated (Cosgrove, 2008; Herb, 2004; Jokela and Linkola, 2013; Nogué and Vicente, 2004). This is done, for example, by signifying and creating 'sacred' or 'poetic' places for nations, outlining the visual appearance of nation, and concretizing the metaphors and allegories that are connected to the national characters (Daniels, 1993: 4-5; Häyrynen, 2005: 29-34; Smith, 1991: 65-66).

Tab 3. Language and landscape have remained as the two pillars for national identity and collective memory in contemporary nation states.

\begin{tabular}{|l|l|l|l|}
\hline & Finland & Estonia & Latvia \\
\hline Official language(s) & Finnish and Swedish & $\begin{array}{l}\text { Estonian (including } \\
\text { sign language) }\end{array}$ & Latvian* \\
\hline $\begin{array}{l}\text { Recognised regional } \\
\text { languages }\end{array}$ & Sámi & - & $\begin{array}{l}\text { Livonian is } \\
\text { considered an } \\
\text { indigenous language } \\
\text { and has special } \\
\text { legal status. } \\
\text { Latgalian written } \\
\text { language and } \\
\text { Latvian Sign } \\
\text { Language also have } \\
\text { special legal status. }\end{array}$ \\
\hline Language family & Uralic $\rightarrow$ Finnic & Uralic $\rightarrow$ Finnic & $\begin{array}{l}\text { Indo-European } \rightarrow \\
\text { Balto-Slavic } \rightarrow \text { Baltic } \\
\rightarrow \text { Eastern Baltic }\end{array}$ \\
\hline The term landscape & maisema, landskap & maastik & ainava \\
\hline ELC entry into force & 4.2006 & 6.2018 & 10.2007 \\
\hline
\end{tabular}

* Although a quarter of the population is Russian speaking, it is not the official language.

The temporal orientation of nationally charged landscapes usually leans towards the past. Due to their palimpsestic (e.g., Vervloet, 1984 etc.) nature, they can be treated as historical evidence of the seemingly persistent and ageless bond between nation and territory. On the other hand, landscapes and representations of landscapes can be used for bringing up sites and events that are relevant for the collective memory of the nation. In this sense, landscapes can be compared to what Pierre Nora (1989) calls 'sites of memory' (lieux de mémoire). Such sites are concrete, material nodes, through which the history of a modern society comes into being as an intellectual and secular production, and that shape the fragmented and artificial national histories into coherent continuums.

The sites of memory turn the recollections of the past into 'collective memories that are constructed and transmitted [...] through a variety of cultural practices' (Dwyer and Alderman, 2008: 167) that consciously and unconsciously select and narrate the events and spatial nodes that start to represent the past (Burke, 1989). In a nationalistic context, such representations are tied to the events and elements that support the collective narrative despite touching people's personal memories and experiences only referentially. These elements become embedded in people's identities through collective commemorative practices. Landscapes enrich this process by conveying a spatial dimension that materializes and concretizes identity-political practices legitimizes commemorative acts through a sense persistence of places and gives the past a tangible and familiar nature (Dwyer and Alderman, 2008: 167-169). 
From the perspective of commemorial practices, nationally significant landscapes should be seen as a reflection of the archival nature of modern memory. This memory is made visible through national monuments that often are the most visible signs of the past. The other two are frequently found in guidebooks, the first describing the flora and fauna of a certain place, and the second the imagery, 'a visual construction of something always outside and beyond ourselves, distanced in time and space from the place we now occupy' (Cosgrove, 1998: 80). Landscape imageries select and signify their objects, and turn the mess of individual places and landscapes into something that seems an authentic and unproblematic collection of representations of history and nationhood (see Dwyer and Alderman, 2008). Similarly, they hide the social power structures and political discourses under the seemingly collective, stable and neutral surface (Till, 2004: 351).

Ernest Renan (1882: 3 ) noted: '[...] the essence of a nation is that all individuals have a lot of things in common and also that everyone has forgotten many things'. Apart from storing and recording, then, national memory actively discards and erases (Burke, 1989). At the same time, it attempts to build a systematic and categorised account out of the elements that are being kept (Anderson, 1983: 184-185). A sense of continuity results from the repeated representation of such elements across different fields of culture. This helps in imagining the nations as communities naturally embedded in time and space (Cubitt, 1998: 3-5). The repetition of national symbols in the everyday life, called 'banal nationalism' by Michael Billig (1995), eventually becomes fossilised as tradition, their conventionality no longer recognised or their self-evident position questioned.

Landscape as a marker of national identity is affected by the change of society and its relationship with the environment. According to Anssi Paasi (1996), the building of regional identities follows this change with a delay. In this process, some landscapes maintain their iconic status, adding to their aura of continuity in time, while others become detached from the lifeworlds of the majority of national community, thus losing their significance as shared identity symbols (Häyrynen, 2014). Thus, despite the strong emphasis on its historicity, landscape imagery is frequently updated, and to gain its legitimacy, it must relate itself to the social changes, refer to people's mundane environments and be an active part of shared memories, ideas and emotions (Paasi, 2008: 522). Thus both the content and narratives of landscape imagery are under constant negotiation. This brings us back to Nora's (1989: 19) notion that lieux de mémoire 'only exist because of their capacity for metamorphosis, and endless recycling of their meanings and an unpredictable proliferation of their ramifications'.

\section{Practical applications and discourses}

\section{Suomi 100 - the centennial national landscape imagery of Finland}

Finland celebrated its centenary in 2017 with the Suomi 100/ Finland 100 programme coordinated by the Prime Minister's Office under the umbrella theme, 'Together' (Yhdessä). Altogether, 235 events were registered in the programme and more took place throughout the year. Apart from these events, various projects and products were launched, carrying the Suomi 100 logo or otherwise associating with the centenary. The projects, products and events were presented on the website suomifinland100.fi. The coordination of the programme was decentralized through regional coordinators that were responsible for planning and promoting the events in the counties and biggest cities.

Landscape (maisema) has featured prominently in the nation building process of Finland (Häyrynen, 2008; Jokela and Linkola, 2013; Paasi, 1996, 2008; Palin, 1999; Raento and Brunn, 2008; Raivo, 2000) and it was, as expected, strongly present in the official programme, although far from dominating it. Landscape was mentioned in roughly 200 event descriptions, but it usually was not the main topic. Instead, it was rather used for framing the events or integrating the events with certain places and moods. In many descriptions, the concept of maisema was referred to in metaphoric contexts such as mindscape (mielenmaisema) or soulscape (sielunmaisema) that emphasized a mythical and spiritual connection between the Finnish nation, its citizens and the (natural) environment.

Among the landscape-related highlights were the 'My Landscape' (Minun maisemani) photographic competition and the 'Finnish Landscape' (Suomalainen maisema) publication 
project, both organised by the professional nature photographers of Finland. In addition, Luminous light art ensemble in six locations around the country. Moreover, many field trips to nationally and locally significant landscape attractions were organized, mostly by local or regional nature conservation associations. Landscapes were also mentioned in numerous musical performances that were associated or inspired by the Finnish (natural) landscapes.

Apart from these Suomi 100 events, some remarkable landscape-related oeuvres were organized. 'Our Land' (Meidän maamme) TV series, produced by the Finnish Broadcasting Company YLE, consisted of drone footage from different parts of the country. The series was an example of 'slow TV' with low-speed visual narration, no storyteller, and subtle soundscapes that consisted of classical music. Besides, there was a painting exhibition and a public voting by the Mint of Finland, of which nine of the 27 officially designated National Landscapes (in 1994, the Finnish Ministry of the Environment celebrated Finland's 75 years of independence by selecting national landscapes (Lindhjem et al., 2015: 154)) should appear in a commemorative coin (the winner, iconic panorama of Koli was released to open a National Landscape coin series in 2018).

The visual material produced for the centenary was highly diverse and does not easily lend itself to systematic analysis. The smaller events produced a body of numerous incommensurable landscape representations that highlighted mostly local landscapes with a sentiment of historicity or traditionalism. The national scale was present on a more abstract level, associated mostly with the uniqueness of Finnish (Northern) nature. While the drone TV series was geographically the most representative oeuvre, the photographic contest had the most participatory character, attracting some 7,600 photographers and yielding almost 44,000 images, of which 1,087 have been published in (and later removed from) the Internet. Both the entries and the selections were guided by nature photography conventions, resulting in nature-centred and rather repetitive imagery. Most of the images were middle-to-high quality generic nature shots with sunsets, Northern Lights, forests and waterfronts or picturesque nature formations featuring high among the topics (figure 1). The focus of the competition was in amateur photography, whereas the publication was a parade of professional nature photographers. It was divided into four books, three representing Lapland, lake district and archipelago respectively (Suomalainen maisema, $2014,2015,2016$ ) and one devoted to a geographical overview also covering cultural landscapes (Suomalainen maisema, 2017).

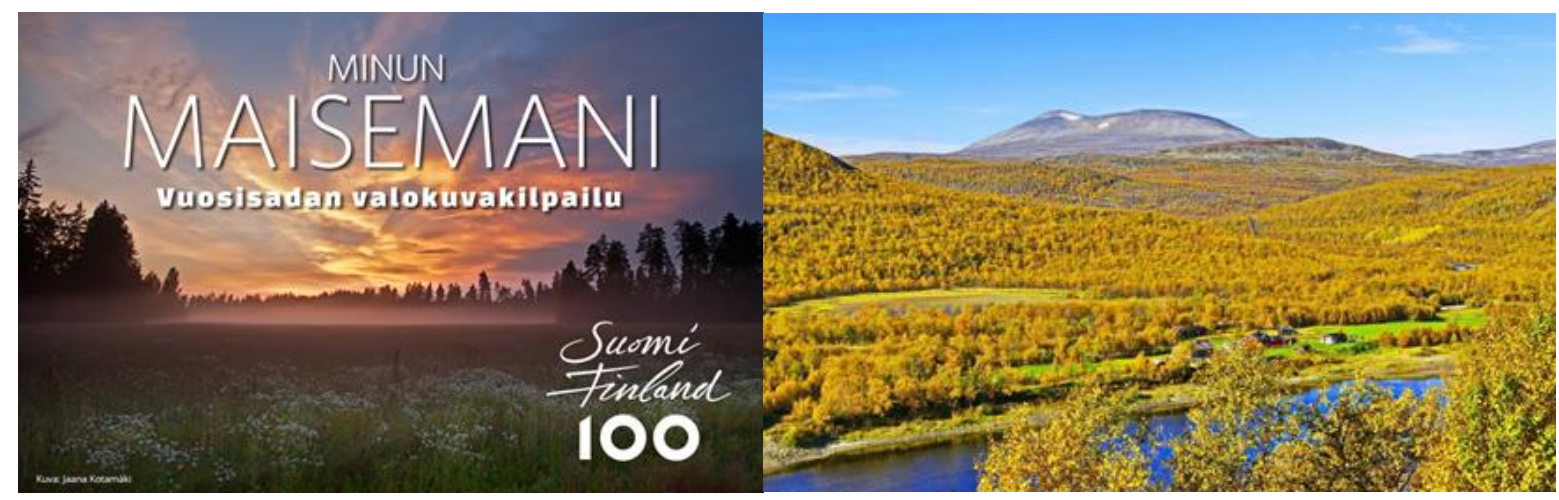

Fig 1. Photograph of northernmost Lapland, winner of the public voting.

Landscape imagery in the centenary programme was strikingly conservative. No serious attempts were made to introduce new elements either in terms of settings or the people depicted - actually the scarcity of people of any kind was notable. Other, less landscape-oriented celebration activities put more weight on the integrative aspects, trying to portray the multi-faceted of the national community. Also, urban or industrial images were largely absent, directing the attention backwards to rural and natural landscapes familiar from the Golden Age of Finnish painting and from the agrarian historical past (see Häyrynen, 2005). Modernity was mostly manifested in plentiful references to WWII, in which the pastoral countryside suddenly became populated by Finnish soldiers in snow camouflage and Soviet military technology. The centrality 
of war imagery in centennial celebrations continued the tradition of celebrating the Finnish independence through the earnest remembrance of the WWII. The militarist tendencies did not go totally unchallenged but were criticised in public debate and social media. Clear signs of war fatigue started to show after the release by the end of the centenary of The Unknown Soldier, the third film version (and a triumph of spinoff products and campaigns) of an iconic war novel by the national writer Väinö Linna.

The way of understanding landscape in the centennial context also highlighted the significance of nature, rural areas, historicity, and sublime regional bonds in the Finnish national mythologies. The remarkable role of local landscapes - and somewhat observable regional imageries - also followed the classic idea of building the notion of a national territory through presenting familiar places and landscapes in national context, and embellishing them with moral and emotional suggestions of the content of nationhood (see Herb, 2004).

Despite the strikingly harmonic and unquestioned content of landscapes in the Suomi 100 programme, there were two minor landscape-related controversies, associated with the nonmainstream elements of the past and contemporary society now and in the past. The fairly simplistic idea of the Luminous light art ensemble was to floodlight six well-known sights in blue and white flag colours amidst the darkness of December night. The project succeeded in capturing positive attention from media attention until it reached the Saana fell in the most northwestern end of Finland, a traditional sacred place of the indigenous Sámi (Sapmi) population (figure 2). The patriotic spectacle was little appreciated by representatives of the Sámi community, who interpreted the act as cultural appropriation by the dominant Finnish culture. The spectacle was conducted in cooperation with the Sámi Parliament of Finland (Sámediggi), the representative body for people of Sámi heritage, but the exclusion of Sámi culture in the official material and descriptions (together with the emphasis of state boundaries and Saana's location in the 'wilderness') gave ground for criticism.

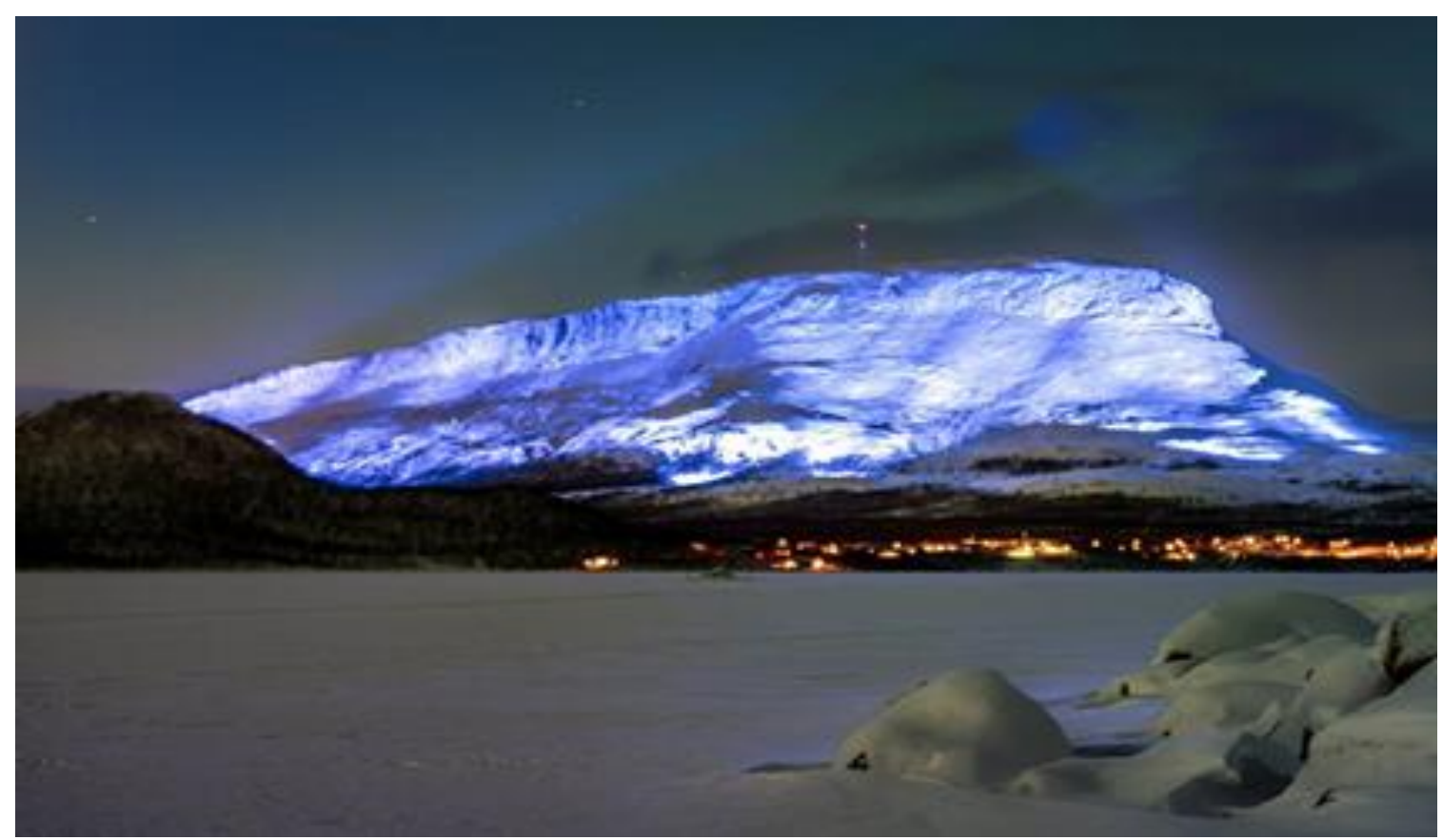

Fig 2. Saana fell, the holy mountain of the Sámi, illuminated in Finnish colours (photo: Suvi Mansikkasalo / LEHTIKUVA).

Another controversy, associated rather with the national historical imagery than the national readings and understandings of landscapes, followed the decision of the Mint to include in the commemorative series, a coin about the execution of Finnish Red Guardists in a wintery landscape during the Civil War of 1918. The coin was part of a coin series that was designed under the title 'other side of the coin', and it was meant to represent the unification of the Finnish nation after a traumatic civil war. The other side represented the tower of the Helsinki Olympic Stadium that was erected in 1938, the main venue of the Summer Olympics in 1952, and that 
symbolizes the recovering from the WWII and internationalization of the Finnish nation state. Somewhat ironically, the tower happens to be white. After a short public debate the coin was withdrawn as 'improper'.

The centenary of Finnish independence has been followed by a memorial year of the Civil War, similarly coordinated by the Prime Minister's Office but in a considerably lower key. The memorial year entailed exhibitions, publications, learning material packages and events. A corresponding overall tendency of depoliticization may be noted in both the centenary and the memorial year. Accordingly, the Civil War has been rendered as an unfortunate human tragedy regardless of the side from which it is being looked at. However, dissonant issues such as the grim fate of women Red Guards or the poor conditions of the prison camps after the conflict have not been altogether avoided and have stirred some public debate, markedly differing in tone from the consensus-seeking centenary.

\section{Eesti Vabariik 100 - blue, black and white collaborative landscapes}

The Republic of Estonia's (Eesti Vabariik - EV) centenary celebrations are coordinated by a government committee consisting of five ministers, the State Secretary and a representative of the President of the Republic, chaired by the Prime Minister. The centenary is feted from April 16, 2017 to February 2, 2020, commemorating the making of national borders and all other important milestones of statehood. The Estonia 100 celebrations consist of five different thematic stages: our land, our state, our people, our freedom and our future, divided into 12 sub-programmes. The Estonia 100 steering group and the Estonia 100 organising committee have been established within Government Office, and are tasked with organising the celebrations together with the people of Estonia (ev100.ee/en).

The Estonia 100 festivities will for the most part be shaped by the people of Estonia themselves, as this is intented to be everyone's celebration. 2018 was also the European Year of Cultural Heritage, so many backward looking and heritage cultural landscape events concurred. The jubilee programme that features thousands of events is participative, all-inclusive and futureoriented, in line with ELC democratic turn. The centenary programme will engage almost every area of life and give Estonian communities around the world a chance to look back at the past, highlight the present day and set new goals for tomorrow to be both ancient and innovative, curious and self-confident. All (i.e., groups of friends, local communities, NGOs, ministries, businesses, associations and other organizations) can receive and make gifts in the form of events for Estonia's centenary listed on ev100.ee web page and smart phone app. The web page has English and Russian translations, sign-language videos, a section where official logo can be customised etc. A lot of attention has been paid to the design of the logo (figure 3), visual imagery, updated regional folk patterns and social media linkage (\#EV100, \#EV100kingitus [gift]) (ev100.ee/en).

The word for landscape (maastik) is not much older than the republic itself, invented by poets and painters in the beginning of the $20^{\text {th }}$ century. Its scientific origins share common roots with Finnish tradition. The word was not used much outside academia, in which meanings derived from German and Russian, an where the concept of maastik was used alongside with both the German Landschaft (ландша'фpm) as well as French paysage (пейзаж). In everyday language maastik often connotes a natural scenic view. In the 2000s, the word gained momentum and was used loosely for 'area of expertise' or 'field', e.g., banking or music landscape (Palang et al., 2011; Peil et al., 2004). It thus has become the backbone of national identity in 2018 (ev100.ee/et/maastikkui-rahvuskehandi-luustik).

Indeed, in 2018, Estonian Nature Protection Society - ELKS (Eesti Looduskaitse Selts) presented the National Landscapes, thus finalising a project that had been revolved around a quarter of a century. The first selection was done by ELKS task force. In addition, author Juhani Püttsepp and photographer Ingmar Muusikus put together a series of 50 illustrated stories also published in newspaper (Maaleht) and ELKS home page (elks.ee/teated/rahvusmaastikud). Public sentiments were possible to transmit via Facebook, e-mail and phone during March 2018. A search of a balance in imagery can be seen: mostly rural places and towns, nature, minority landscapes and one industrial oil-shale site were included. As usual, only summer images of 
landscapes circulate (except for Christmas cards) the project marked a remarkable shift: half of the print-run has summer and half winter landscape cover. The organization were supported by the Environmental Investment Centre and due to that, the book could not be purchased from a conventional bookstore. In 2018, also a national park of Alutaguse was found, as the sixth national park in Estonia.

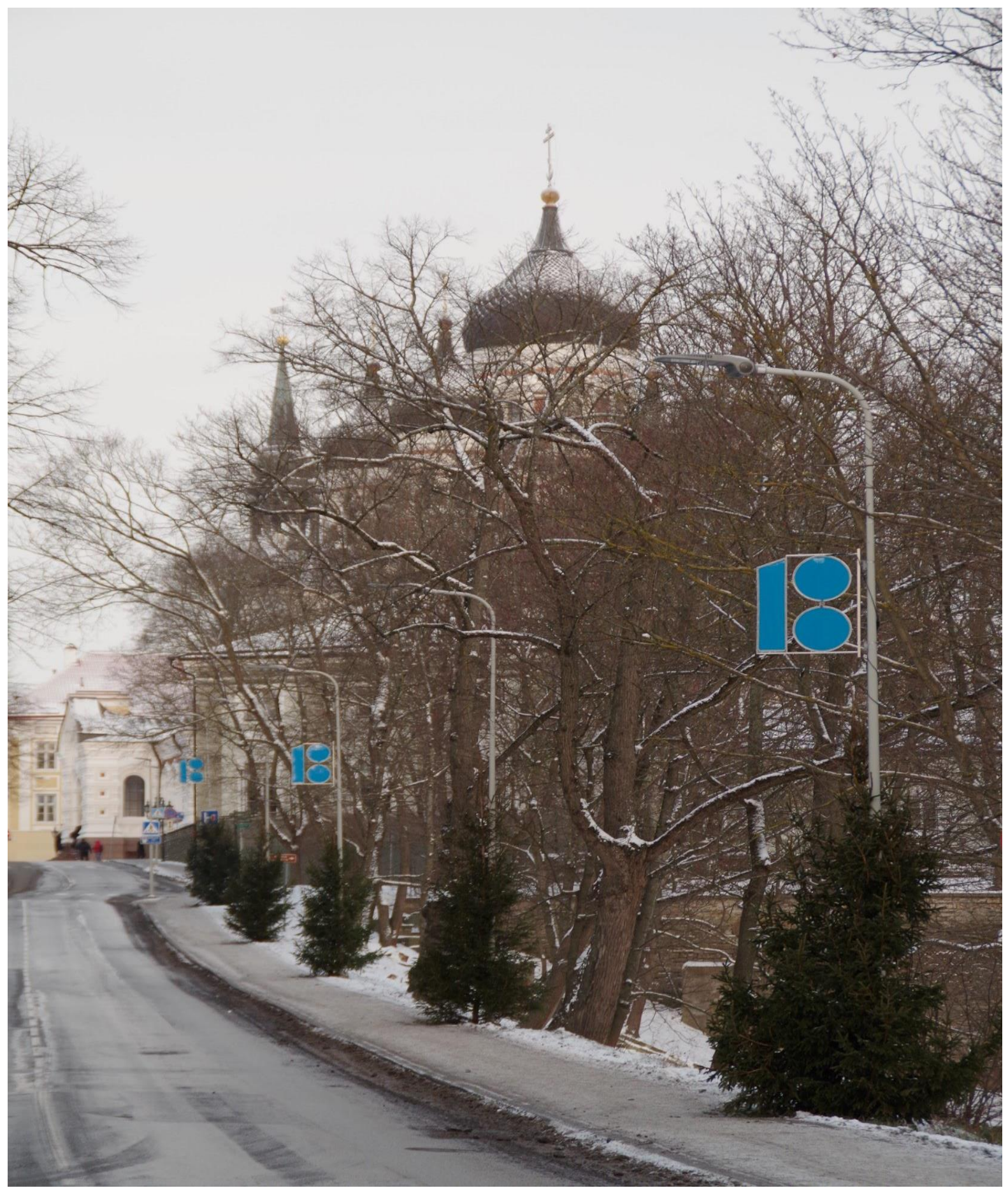

Fig 3. Estonia 100 institutional logo forms from the time span 1918-2018 accentuating 18s, which can be read as 100. The picture is taken on Toompea, Tallinn, stronghold mentioned in national epic, with castle of Danish and German knights, now the seat of Government and Parliament, opposite the Alexander Nevsky Russian Orthodox Cathedral (pictured), built in the peak of Russification in 1900 - landscape as palimpsest (photo: Anu Printsmann 22.12.2018).

There are few events that relate directly to landscapes, but the concept is being used loosely in many events, e.g., a new song featuring 2000 place names, free concerts and $175 \mathrm{~km}$ long picnic 
table 'Along the Border' (Mööda piiri) in the fresh air. In addition to traditional celebratory events like singing and dancing, producing of EV100 logo embedded paraphernalia more than ever before, attention has been paid to nature, architecture and good public space. For example, more than a dozen small towns had architectural competitions to reconfigure their central squares. Students all over Estonia have been planting acorns and growing saplings for the Estonia 100 Oaks project to plant oak groves in honour of the centenary. A landscape architectural masterpiece of Estonia's Victims of Communism 1940-1991 (memoriaal.ee/en) was opened on re-independence day (compare to Latvian 'Garden of Destiny'). Estonia will also be promoted in the public space of a number of European cities with a 'Digital Street Art' creative solution, combining graffiti, history and digital technology. Undoubtedly one of the greatest events was the World Cleanup Day on September 15, 2018, which was a gift from Estonians to the world (ev100.ee/en).

The film programme included four feature films where landscape is mainly used to convey the inner moods of protagonists. The film 'Truth and Justice' (Tõde ja õigus) is based on a novel of the same name that has been compared to five-volume mire draining handbook. One documentary on Estonian 'untouched' nature (Tuulte tahutud maa) featuring yearly life cycles of animals, mainly in coastal and riverine landscapes. A children's movie (Eia jõulud Tondikakul) features a city girl who engages in rescuing pristine forest.

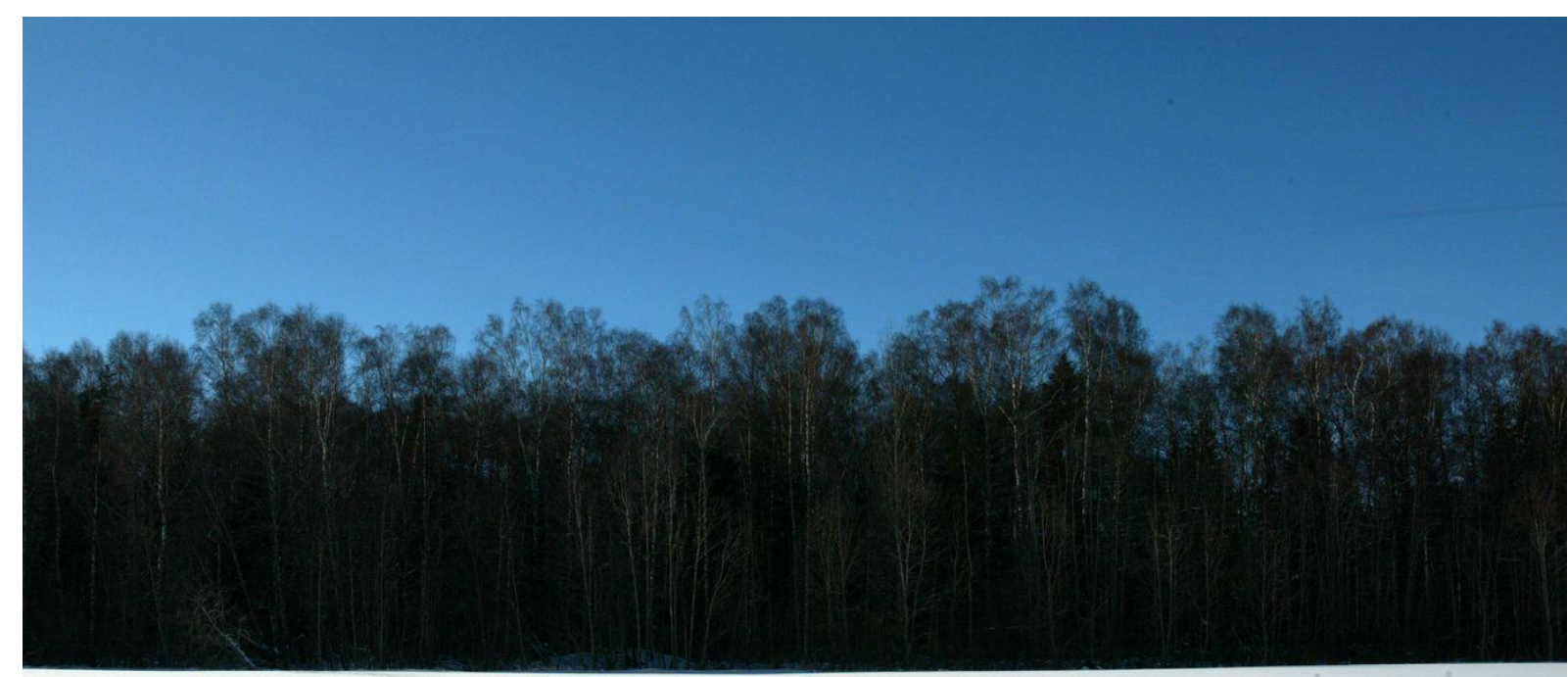

Fig 4. Not a touristy summer landscape but proof of belonging to the Northern countries. Estonian national tricolour (blue-black-and-white) in winter landscape. Photo: Tairo Lutter / POSTIMEES, 19.02.2013

In TV, in addition to celebratory jingles edited but participatory drone videos with appropriate popular music were shown (https://etv.err.ee///eriprojektid/minu eestimaa). Estonian Public Broadcasting has a series of jingles, e.g. it has brought historical urban photography to life for the $95^{\text {th }}$ anniversary (2013); in 2016-2017, introduced peculiarities of Estonian language (e.g., national can be translated into Estonian as 'state' or 'nation'); in 2018, famous Estonian paintings were set in motion; as 2019 is declared the year of the Estonian language (in line with UNESCO's International Year of Indigeneous Languages), now the search for the most beautiful word is going on.

The underlying theme of the centenary has been collaboration and participation with some curating. Both on $95^{\text {th }}(2013)$ and $100^{\text {th }}$ jubilees, 'Estonian Minute' photo event was held, organized by Estonian Association of Press Photographers. On 24 ${ }^{\text {th }}$ of February at 13 o'clock, 
a snapshot should be taken and sent to the largest Estonian digital photo exhibition held at Estonian National Museum. Both Estonian residents and foreign visitors were asked to take a picture of their surroundings, people, mood, objects or nature. Everyday life: things, landscapes and streets that will definitely change. It was not important whether one was in the forest, work, at a party table or at home. People took snapshots which will be intriguing, ethnographic material, and also orchestrated photos. An idea of re-photography was also introduced. In 2013 the photo event yielded 8,000 photos, in $2018-14,000$.

In 2016, a photo event was organized by Estonian Daily Newspaper (Eesti Päevaleht) to picture anything with blue-black-and-white colour combination - the colours of the national flag of Estonia. It could be random objects standing side by side, food, clothing choices, colours on bird wing. This resulted also as a yield of landscape photography some landscape photography (figure 4). These pictures were collaged together to form an enormous flag during re-independence week celebrations, virtual global sing-along on the Song Festival Grounds.

Landscapes are not only visual. The Estonian Folklore Archives (Eesti Rahvaluule Arhiiv) has been responsible for collecting oral and written memories. In the beginning of the $2000 \mathrm{~s}$, they published a three-volume set of 100 Estonian life-stories describing the $20^{\text {th }}$ century. The questionnaire 'My Landscapes' (Minu maastikud) was open for competition 24.04.201515.01.2016 not fitting to the centennial celebratory time frame. Over 300 people contributed with 2,160 pages and 1,174 photos, additionally map outtakes, plans, drawings and illustrations, and 22 hours of recorded memories and video material. One of the winners offered an insightful over the years compiled and recorded the chronicle of 'phosphorite war' destroying farms in 1960s1980s that was one of the impetuses for re-independence. Another noted works touched Tuhala karst region, the seascape childhood memories (due to Soviet regime, access to the sea was fairly limited) and using of cross-trees in funeral processions in South-Estonia. It was stressed that better contributions tied collectively important themes and topics with immediate personal environmental experience.

Recently, the debate on the use of natural resources is gaining momentum. How much forest felling should be allowed in state-owned forests? After Soviet period, large agricultural lands fell out of use in 1990s and overgrowth was the biggest concern. In mere 25 years, the general public feel that too much forest is clear-cut. Mires that were excessively drained during Soviet period and created into protected areas in 1981 are now being restored, which is counterintuitive to 'Truth and Justice' logic. The recollections of phosphorite war remind them that more than $80 \%$ of Estonia's electricity comes from oil-shale.

Another discussion is if the Estonians are more sea or forest people. The Soviet layer disrupted the maritime culture. Currently, Estonian urbanites favour mires with hiking trails.

'Estonian 100 Treasures' (Eesti 100 aaret) is a smartphone GPS-navigating landscape game that offers the opportunity to get better acquainted with Estonia, to discover its development history and people. Some of them are in towns, for others a longer hike is needed with wellies. The selection is varied as the story of Estonia. It started with pitching ideas to Estonian National Heritage Board in 2015, then the committee from Heritage Board and EV100 programme committee task force selected 150 for the public vote considering county representations, natural and cultural heritage, well and less known places (eesti100aaret.ee).

Hiking gained completely new dimensions in the last couple of years in Estonia. Jubilee celebrations started on April 16, 2017, marking 100 years when Estonia was compiled from Estland and part of Livland provinces and the hike was along that province border. The Estonia 100 hiking series with close to 200 events had hikes on waterways, hikes in nature reserves and adventure hikes, open water and heritage hikes, nature observation, mushrooming and berry picking hikes, bog hikes, car and other motorised vehicle hikes and also kick-sled and skate hikes. State Forest Management Centre managing roughly a quarter of Estonian area has contributed a lot with its hiking paths.

In addition to 'official' Estonia 100 programme that everybody can update, there are also more informal sentiments performed (figure 5) that also made people ask whether every celebration is appropriate. If the War of Independence is commemorated as the difficult beginning of statehood, 
then WWII and Soviet landscapes are completely dismissed. Some minority landscapes are 'on the picture' as public selection has been curated but otherwise land, territory, nation, language and landscape seems to form indisputable conformity.

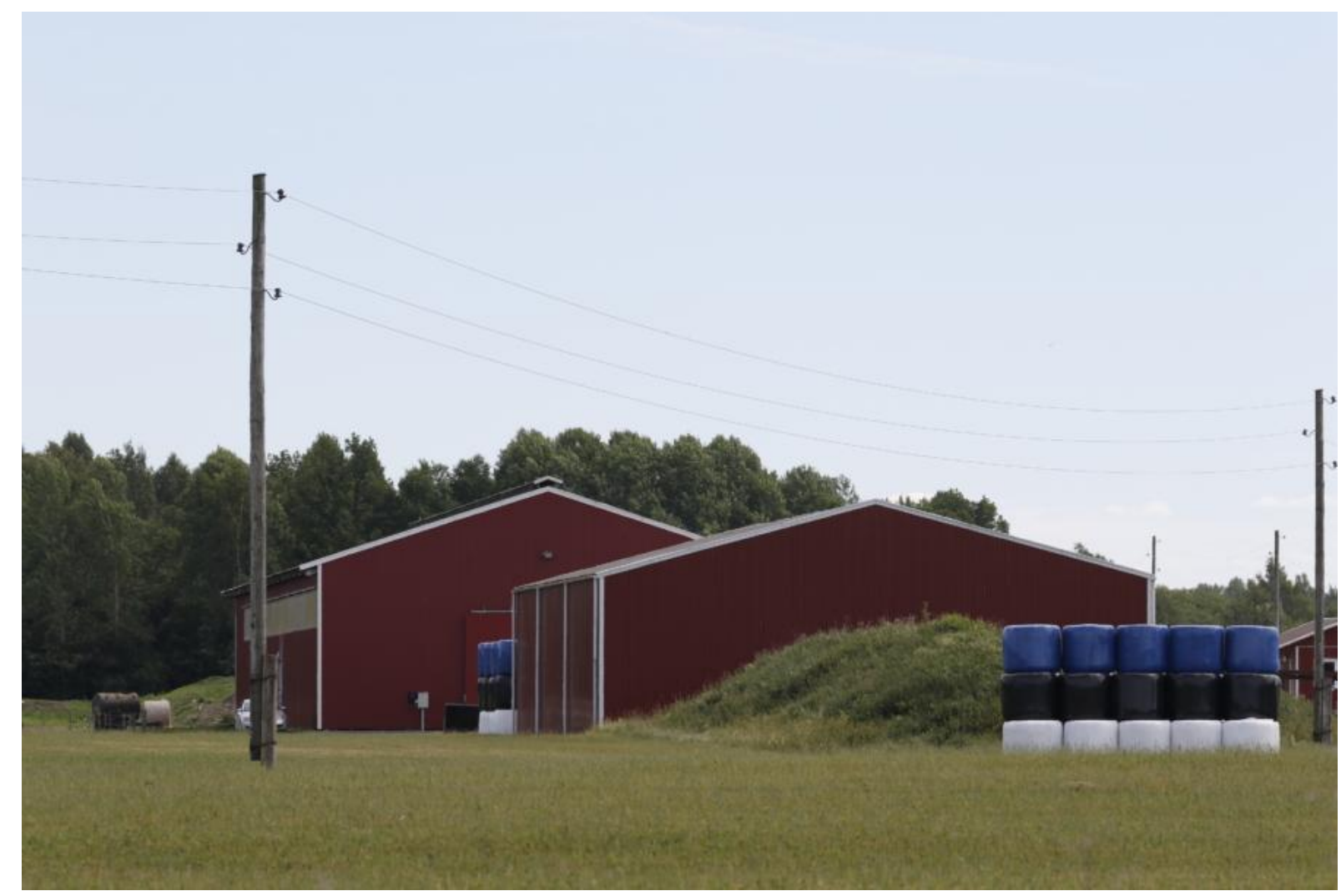

Fig 5. How the public celebrated. Silo pile in national tricolour. Photo: Urmas Lauri, 28.06.2018

\section{Latvija 100 - landscapes of then and now}

Latvia is celebrating its centenary in 2018 with Latvija 100 / Latvia 100 programme coordinated by the Ministry of Culture with the central message 'I am Latvia' (Es esmu Latvija), stressing the main value of Latvia - its people. Since Latvia is celebrating the centenary for five years (2017-2021), more than 2,000 activities are foreseen and their scope is rather rich in geographical, thematic and temporal variety. Platform latvija100.Iv holds the main information on centennial programme, aims and participants. The headquarters of the centenary is the main building of the National Library in Riga, which is also the central spot for various gala exhibitions and events.

Landscape-related projects are primarily associated with one of the Latvia's centenary objectives, 'to admire the beauty of nature, cultural diversity and singularity', and few of these activities that have landscape as the central topic, while numerous others mention landscapes in their descriptions. In some occasions, the titles employ the word landscape more as a poetic framework in relation to art, symbolism, nature values or countryside. This shows the recent trendiness of the concept, which for a long time has been neglected in Latvia. Therefore, it is particularly interesting, how the state, NGOs, and even private companies captured and explored the concept to strengthen their respective interest and influence. Nature protection agencies (funded by the Administration of Latvian Environmental Protection Fund) and various ministries are among the most powerful actors in these landscape-orientated displays.

Even though all of the landscape-related projects have different objectives and means, they all revolve along common themes: landscape 'then and now', nature, landscape beauty, personal values and stories, and disappearing landscape features. 'Landscapes Talk. Nature's Diversity in Latvia's Landscapes' (Ainavas runā. Dabas daudzveidība Latvijas ainavās), a project launched by the Latvian Fund for Nature (LFN), was one of the first ones to address the landscape change, 
introducing the popularity gained syntagma 'landscape then and now'. Using the metaphor of landscape reading, the LFN invited the people to listen to what landscape has to say about its nature values, how people act in landscapes, and which elements are disapperaing from the landscapes. The main project's showpiece was the comparison between current and interwar landscape photographs of places and vistas between the interwar period and today (figure 6). Another backbone of the project was the single farmstead as the hearth of rural landscape and as the subject of the qualitative place-making ${ }^{7}$, thus keeping up with the pastoral vision of the many historical landscape narratives (Skultans, 2001).
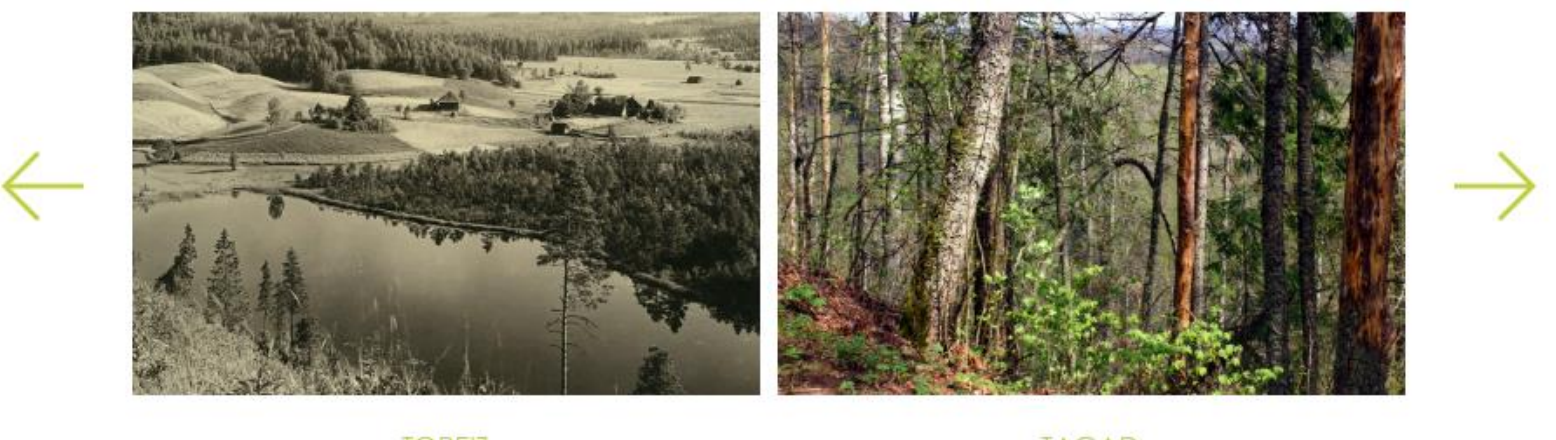

$1 / 44$

Fig 6. The screenshot of 'Landscapes Talk' homepage showing a picture pair of the same place then and now. Source: ainavasruna.Iv

This activity strengthened the already embedded discourse of the ideals of Latvian agrarian ethnoscape (Schwartz, 2006), that is, the sentimental appreciation of the so-called Latvia's 'golden age' in the 1930s, when the greatest part of population lived and worked in the countryside, but it also added to the discourse the angle of modern understanding of biodiversity. Very similar approach was adopted in the project for national television, entitled '12 Elements in Landscape', in which each episode was dedicated to the particular landscape elements (trees, rivers, bogs, meadows, farmstead, manorial parks, etc.), and again, focusing on how the particular places looked 'then' (using mainly footages from old documentaries and popular movies) and how the same places are managed and inhabited 'now'. Nature protection experts, discussing the contemporary values, lost features and actual management practices, and local stakeholders (quite often national celebrities), sharing their stories and views, were the main actors in these series. Idea of landscape comparison was carried out also by the Ministry of Agriculture in the photo contest, entitled 'the Countryside of Latvia Through Times' (Latvijas lauki laiku griežos), where people were invited to submit the representations of rural landscapes and people's work in the beginning of $20^{\text {th }}$ and $21^{\text {st }}$ centuries.

It is quite interesting that these aforementioned projects (and many others) were designed and carried out through active public participation, and not only by sharing their personal landscape values and by participating in joint-works on particular sites, but also by their engagement in discussions on what landscape values are and how, according to the project holders, landscapes must be managed to preserve these values. Such was also the succeeding project of 'Landscapes Talk', by the LFN, called 'Go Out in Landscapes!' (Dodies ainavās!), which organized guided walks in particular landscapes, public round tables and storytelling events, but also landscaperelated seminars for professionals, all of which were more or less saturated with nature protection and biodiversity topics. At least for nature protection agencies, such as the LNF, this was an excellent platform to speak about biodiversity by bringing it up to the landscape level and thus developing this particular notion of landscape as never ending taskscape, using Ingold's (2000) term, that is, the notion that landscape is a continuous work and the best way to do it is to follow the ideology of harmony of man and nature living together, where man is the steward and caretaker of nature (Meinig, 1979: 36).

\footnotetext{
7 https://www.ainavasruna.Iv/uploads/editor/Ainavas_runa_Petijums_vienseta_ainava_ViA_2017_final.pdf
} 
If the above-mentioned projects talked about the national landscape values rather in a somewhat hidden form, there were activities that quite directly addressed the question, what actually is Latvian national landscape. Among them, a national scale project, entitled 'Landscape Treasures' (Ainavu dārgumi) (figure 7), launched by the Ministry of Environmental Protection and Regional Development (MoEPRD) together with the National Library, is worth a closer investigation. First of all, this was the most official landscape-oriented project, highlighted as the main activity in 2018 along with such important events as Song and Dance Festival, Latvian Police Centenary, Latvian Flag events and Freedom Street Stories. Its main objective was to collect the people's 'treasures' no matter how local and personal they are, and then, by the contest of online voting, to nominate ten 'treasures' in each of the five Latvia's planning regions, thus ensuring the territorial coverage. Since the concept of landscape was not clearly defined in this activity, the people (not only individuals, but also institutions, e.g., local tourism centres and municipalities) made very diverse submissions: from large boulders and ravines to former manor centres and old towns, from very local and intimate places to already acknowledged and remarkable landscapes.

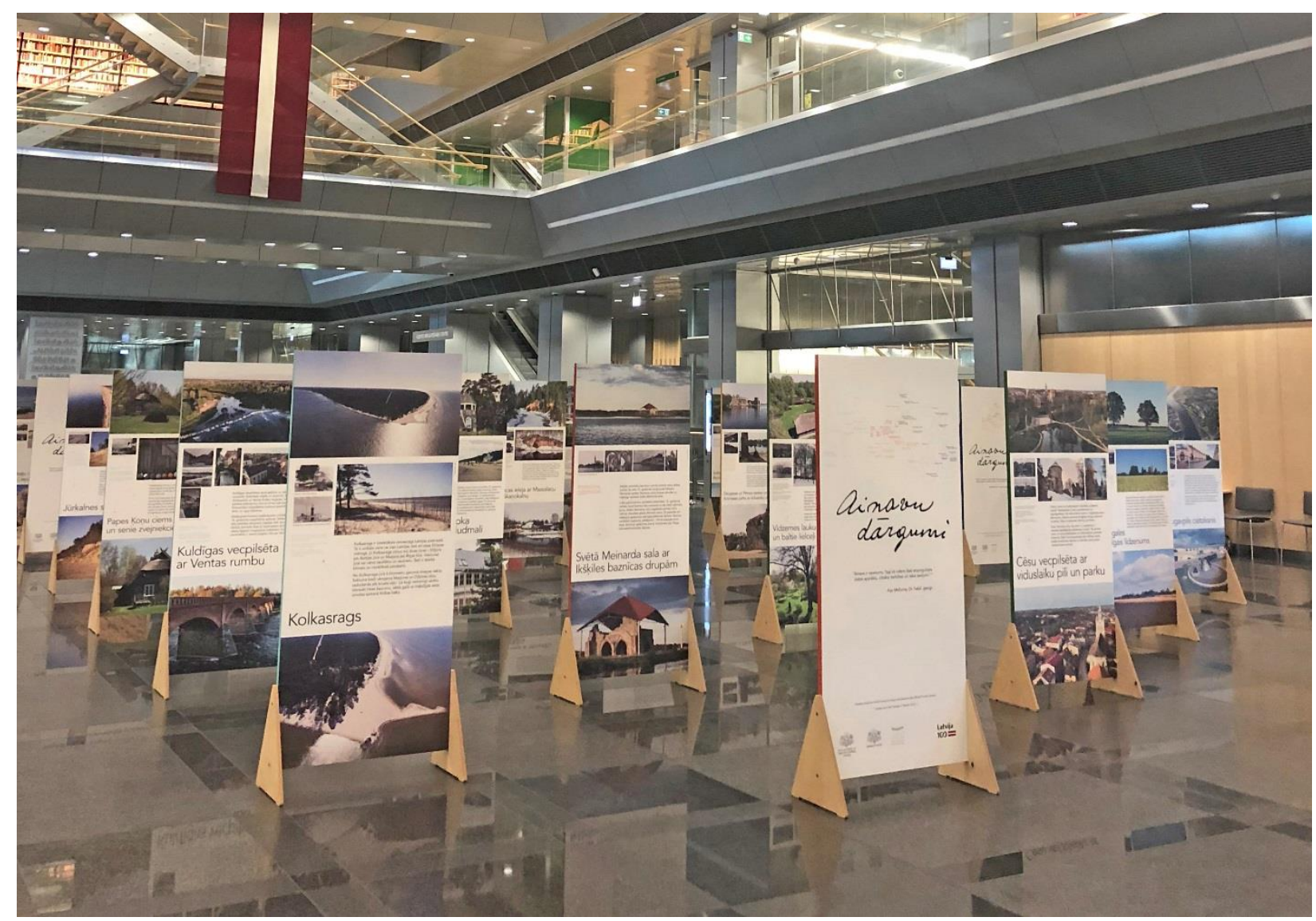

Fig 7. Picture from the gala exhibition of 'Landscape Treasures' (Ainavu dārgumi) at the National Library. In the front stand - the logotype of 'Landscape Treasures', elaborated by borrowing the handwriting of the most iconic Latvian landscape painter and founder of Latvian Academy of Arts - Vilhelms Purvitis.

Altogether, there were 928 submissions in three month's period, of which for the further public voting, 243 'landscape treasures' were nominated. This scaling down of the designations was done by the Regional Planning Agencies and the special landscape expert committee, coordinated by the MoEPRD. Despite the fact that this project initially was intended as the Vox populi, the intervention of the expert committee in the nominating procedure was crucial in adding the national scale to the final result. Apart from the other projects, especially the ones run by nature protection agencies, whose agenda was mainly to explain, discuss, and quite often to demonstrate what is wrong with the contemporary landscape, this activity discloses what the state's national landscape in the beginning of $21^{\text {st }}$ century is, and what could be more important, it enables the discourse of what the regional identity in terms of landscape is, on which the debates recently have been but scarce and arbitrary. 
Among the already acknowledged places and landscapes, legitimized either through Protected Landscape Areas or tourism platforms, 'landscape treasures' consist also of lesser known, forgotten and in some ways marginal landscapes, for example, the former fisherman village Pape at south-western corner of Latvia (now re-populated largely by Lithuanians) or the rural landscape of depopulated Veclaicene, which is located at the eastern part of Latvia with the border of Russia. The majority of these 'landscape treasures' is related to nature elements (large natural bogs, seacoast, river mouth, large lakes, river valleys) and townscapes (old centres, villages, particular architecture, fortifications, monuments). The rural landscape as such (with spectacular views and traditional elements) is valued especially in the upland part of Vidzeme Region, which already historically represents the proper Latvian ethnoscape. Landscape nominations also show respect to the Latvia's history, representing landscapes of prehistoric objects (a hillfort and a lake dwelling settlement), the first settlement of crusades in Ikšksile, as well as several landscapes of manors and palaces (mainly in the Zemgale Region). While religious landscapes with Catholic churches and crucifixes are exclusively attributed to the Latgale Region, the so-called Latvia's Catholic Country. Among all the man-made landscapes two industrial places were nominated the landscape of Pļaviņas Hydroelectric Power Plant, which was built in the Soviet period, and the former paper-mill in Lìgatne.

The visual material produced for the centenary comprises innumerable mainly amateur photographs, but also paintings and videos. Among them, the most popular are the already mentioned photo-pairs of landscapes 'then and now', which seems to be growing into kind of a movement of landscape comparison, surrounded by somewhat a negativity of how landscapes look now. This was made possible partly on account of the already popularity gained digital archive 'Lost Latvia' (Zudusi Latvija) at the National Library, which offers numerous landscape photo representations of the $20^{\text {th }}$ century. In building up the visual collections, the submissions of mere photographs were not the sole participant's activity, many projects offered to the people to share their subjectivization with places and landscapes. For example, in the 'Landscape Treasures', people were asked to submit, along with the visual material, their stories about the landscapes or at least to indicate, why this landscape is important to them or to the nationhood. The World Wildlife Fund Latvia that carried out a project, named 'Riches of Nature', invited the people to merge with natural landscape and to submit the photo of this act along with the commentaries on the depicted nature values and the self. The visual material produced by the professionals was of a minor presence among these activities. The drone footage was used by the Tele2 mobile operator in the project 'Latvian Alphabet" of Latvia's Landscapes', depicting the forms of landscape elements for all of the letters of Latvian alphabet. Professional photographers were involved also in the 'Landscape Treasures' activity for capturing the final 50 treasures and creating materials for the travelling exhibition and the digital catalogue.

Last, but not the least, a very specific activity that, in fact, resulted in the creation of a new landscape - saturated with designed objects of symbolic meanings, is the project 'Garden of Destiny' (Liktendārzs). It is a privately owned 22 hectares of a small peninsula next to the Daugava River, which is still being landscaped and developed through public donations with the aim to realize the metaphor of the nation's continued growth and development upon devastating historical time spans (figure 8). Its opening gala was at the $100^{\text {th }}$ birthday of Latvia, on November 18 (2018). 


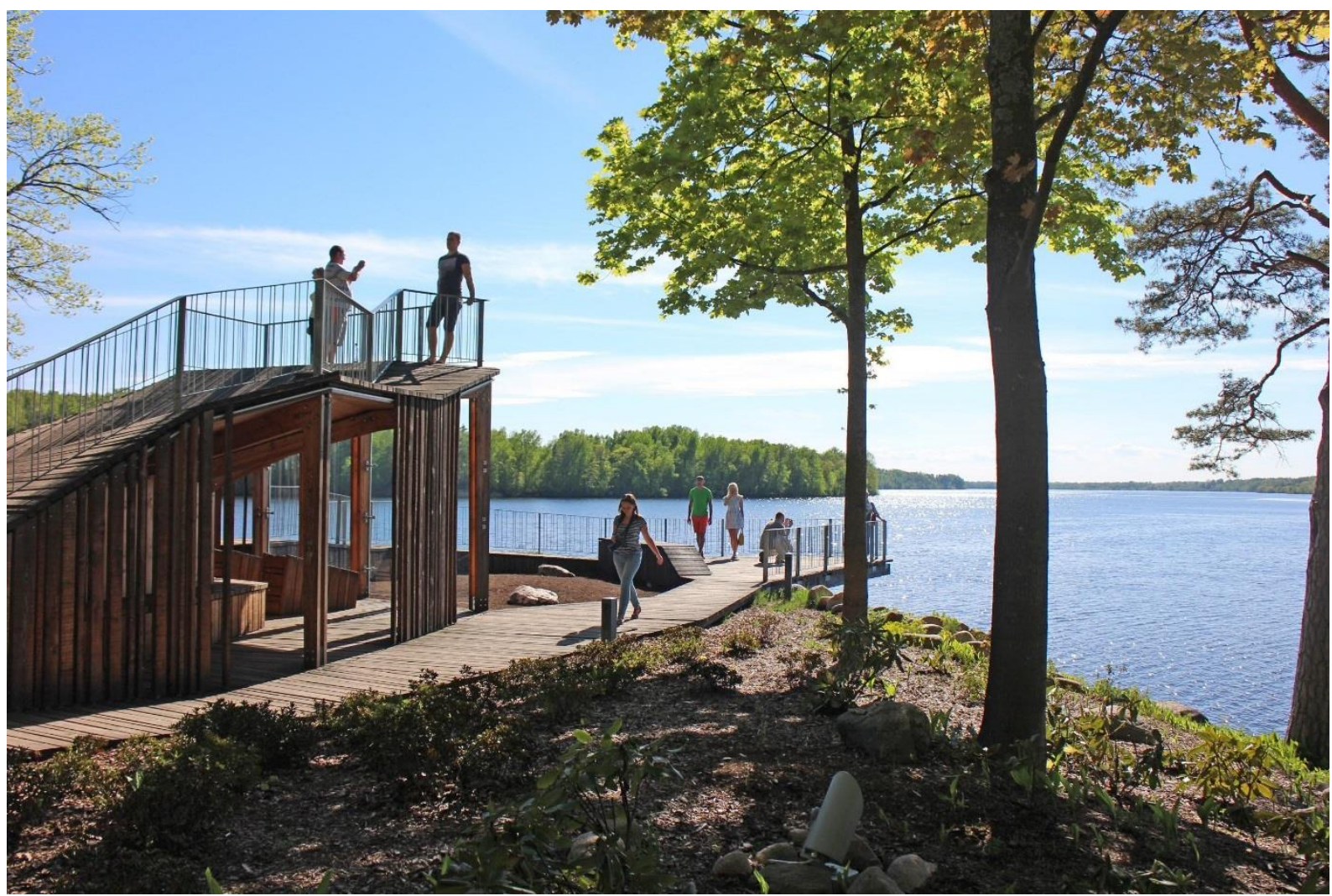

Fig 8. Harmony terrace at the peninsula designed as a place where one should feel the flow of time looking on the flows of 'destiny's river' - Daugava.

\section{Discussion}

There are many similarities in the ways in which Finland, Estonia and Latvia have handled landscape in their celebrations. However due to history, language and understanding of the concept of 'landscape', some of the approaches within national identity framework have been slightly different.

First, the concept of landscape usually refers not only to landscapes as such, but is rather used in some metaphoric meaning, using poetry or literature. Good examples here are the Finnish approaches of mindscape and soulscape. This reflects the mythical bond between a nation and its landscapes; landscapes are said to represent not only the concrete locations but also a spiritual connection between a nation and space. Since every landscape is experienced individually, these social myths are naturalized and internalized through the repetitious landscape representations in contexts that support and renew these myths.

The tension between statehood jubilee and the still remains nevertheless. Landscape connects only slightly to the former, which is more space and border bound and more to the latter. Yet, the nation states are not socially homogeneous but consist of contemporary versatile interest groups. There seems to be a window of opportunity for nation states to slowly open up to minority landscapes.

The Finnish centenary programme offers many examples of Vergangenheitsbewältigung, management of the past. It was led centrally and from above, with careful screening of the projects and events. Unsurprisingly, much room was given to clichéd national symbols, such as iconic natural landscape, although the programme also contained a wide variety of landscape-related local events and activities. On the other hand, the historical or regional narratives are traditionally linked to the national representations, were generalized and depoliticized with the major exception of WWII. This may be interpreted both as an attempt to steer clear of divisive issues and as an indicator of changing collective memory base, in which certain details of geography or historical chains of events may have lost some of their earlier importance in framing the national identity. 
The former interpretation is backed up by the fact that although several cultural institutions and communities took part visibly in the celebrations, the relative scarcity of the cultural debate around them does not suggest a thorough nationwide mobilization nor the process of self-reflection. Here, the comparison with the memorial year of 1918 is interesting, as the latter clearly has a narrower societal scope but also a markedly more critical focus.

The second interpretation would suggest an increasing distance of the population from former identity bases such as established regional identities (Paasi, 1996), nature peripheries (Peltonen, 2000), the agrarian way of life (Vallius, 2013) or historical lieux de mémoire (Raivo 2004). National representations originally gained their ideological force from being able to penetrate the lifeworlds and memories of national subjects. As these keep changing, national representations involving redundant aspects of everyday life may either lose their significance or become fossilized and ritualised through repetition and mediation (Billig, 1995; Halbwachs, 1950).

In the landscape-related activities of the Finland 100 programme, efforts were made both to reestablish the connection between national representations and the everyday life and to widen the traditional scope. They included among other things thematic trips and hikes, garden visits, concerts, food events and documents on urban nature, located around the country. Such small and engaging activities somewhat diversified the media space of the centenary but did not dominate it or seek to contest the more conventional national representations. On the other hand, only a minor section of the programme openly dealt with landscape in the first place. Other parts of the programme addressed the ethnic and linguistic makeup of the Finnish society, the role of immigrants etc.

The careful framing of landscape may be seen against the background of increasing political rightwing populism and extremism in Finland and their tendency to redefine national symbols for their own uses. In the programme of Finland 100, the retaining of the unifying character of landscape was clearly prioritized, which required a conscious evasion of all divisive topics and thus led to a watered down version of the national narrative. National landscapes acted as a recognisable, yet allegedly neutral backdrop for a common feel-good celebration, as far as possible pre-empting open political interpretations. This backdrop however acted selectively by mainly suggesting an ethnically Finnish population with a predominantly rural past.

To sum up, landscape featured in the Finland 100 programme as mainly apolitical and nostalgic element, from which social inequalities, exploitation of nature, the effects of urbanisation or (apart from WWII) historical tensions, were largely absent. The traditional national representations were recognisable but the geographical representation of landscape was less in evidence. The overall role of landscape in centenary celebrations appeared to be a formal reassurance of continuity, balancing the view of a changing Finnish society and way of life in an increasingly turbulent global setting. A similar case of official resorting to old national landscape imagery had earlier been seen during the 1990s, when the Finnish government pulled up a list of 'National Landscapes' in the middle of the EU integration debate.

Latvia's centenary turned out to be a necessary context for landscape to become once again a source of national identity. Earlier discourses on landscape as part of national identity can be found in the 1920-1930s, along with the building of the nation-state (e.g., Schwartz, 2006; Zarina and Krumberga, 2018). They were followed by activities to identify territorial identity through nature imageries in the Soviet period that competed with the discourses of the past, as well as the ones that were constructed in the Latvian exile works. During the centenary events, landscape in a way redeemed the meaning of homeland in forms of its natural qualities, singularities of places, regional characteristics and also as reflective of national virtues such as freedom, liberty, independence (Hooson, 1994; Kaufman and Zimmer, 1998). Exemplary here is the project of Garden of Destiny ('a birthday present' to Latvia) that is designed as a place for the commemoration of the nation's hardships, filled with symbolic elements representing both individual stories of wars and deportations, and collective strives for independence. Also, the 'Landscape Treasures" gala event was held under the title 'Freedom, Landscape - Us', wherein landscapes of River Daugava were manifested as a national stronghold, and thus an important icon of resistance against Soviet plans to build another hydroelectric power plant (HPP) there in the late 1980s. 
Nevertheless, the Daugava's landscape of Soviet Plavinas HPP now is listed among the 50 national landscape treasures, hence indicating some contradictions in the articulation of values and, according to Kaufmann and Zimmer (1998), clearly showing the public role of landscape symbolism as a contingent on particular socio-political contexts. It also demonstrates how the image of the landscape can change over time. The analysis of the list of national 'treasures' discloses that the majority of these landscapes are sightseeing hotspots, that is, largely gazing and consuming objects, surrounded with the touristic imaginaries that are often devoid of deeper historical and political meanings. The paramount in this governmental activity was the people's fairly democratic participation in nominating and voting for landscape treasures. What is significant here is that national landscapes therefore are articulated arbitrary as singular and spectacular places without larger contemporary socio-political contexts, except for the interests of tourism industry and nature protection.

In a similar vein, the landscape treasures indicate a shift away from the narratives and images of agrarian ethno-landscape of single farmstead, which according to several researchers (Bunkše 1999, 2001; Schwartz 2006; Skultans 2001), has constituted the essence of Latvian national identity starting from the mid- $19^{\text {th }}$ century. However, the pastoral farmstead landscape values were not abandoned completely and were picked up by nature protection agencies creating the discourse of pre-productivist management practices as a prerequisite for biodiversity and protection of species and biotopes. Learning from landscapes of the past, as well as studying the past and evaluating the rural landscape change, there were the issues that rendered landscape as reflective of a qualitative living environment, targeting quite narrow societal groups that are interested in biological farming, local histories, protective management, eco-tourism and in the trends of green lifestyle in general.

To sum up, since the mid- $19^{\text {th }}$ century, Latvia's landscapes embodied various metanarratives and strives dependent on larger political contexts: ethno-landscape of single farmstead as a singular form of national lifestyle during national awakening in the $19^{\text {th }}$ century and Soviet period, Amberland as the symbolic nation-state territory in the 1920s, the movements of nature protection elements as part of the resistance to Soviet powers. Now, such collective metanarratives seem to have faded away, giving space for individual values and stories about places and landscapes that can be collected, summed up, mapped, represented, liked or disliked, and shared in various medias, but, in particular - social networks.

Overall, the centenary events are held in a highly patriotic, ethnic (Latvian) and nostalgic atmosphere, praising Latvian language, traditions, folklore, independence and remembering the socio-political events and processes that took place in the last 100 years. But thus, similar to Finland, the questions concerning contemporary political issues and future directions (such as cultural and landscape values for ethnic minorities; depopulation, marginalization, ways of the exploitation of forest resources, suburban expansion, shift towards renewable energy) are avoided, as well as are the critical re-examinations of political decisions of the past.

For Estonia, the celebrations brought forward two foci: collaboration and cultural heritage. This is somewhat surprising, as traditionally the definition of landscape used to focus mostly on nature. However, it was only in 2017 that Estonia finally joined the European Landscape Convention and one can only speculate whether the change in the focus has any relation to this step. On the other hand, landscape was brought to the fore through the planning of valuable landscapes in early 2000's (see Palang et al 2011) and the way landscape was used in the festivities somehow continues that trend.

In celebrations, landscapes are visual, but participatory, and everyday more than special. The idea that landscapes are visual was brought to Estonia geography by Granö (Peil et al., 2004), and during the Soviet times, landscape science tried to marginalise this notion, focusing more on nature. To be more precise, Granö argued for landscape being perceived with all senses - using hiking to celebrate landscape is a step in that direction. Also, the use of visual confirms the current image of the country as technologically advanced - much of the activities were done through social media which, unfortunately, is still only able to share visual images and not smells or tastes. 
The visual plays a big role in creating links with the past. As mentioned above, there are two issues that can be observed in our landscapes. Firstly, that not only the $20^{\text {th }}$ century (for $20^{\text {th }}$ century see Palang et al., 2006) has created a layered or palimpsestic structure, and secondly, that due to urbanisation the links with landscape are also changing. Using visual landscape during these celebrations serves precisely for making links between the different layers. The landscapes we see have a certain urban gaze in them. Indeed, landscape still is a 'backcloth of all human activities' but we look at it from a distance, albeit with a certain sense of nostalgia. The picture book curated by the ELKS is a testimony of this. At the same time, the strive towards collaboration and participation, be it in forms of calls to send in photos or ideas tries to generate a collective memory/identity. There is a sense that people have changed and there is a clear need to revise and renew the links with the past, which is perhaps not that patriotic and nostalgic as it was in early 1990s, but it is still important. Estonia tries to notice the everyday and also the differences.

The use of the three colours of the national flag seems innovative. While much of the discussions about identity in Estonia stay on the ethnical or language level, the focus on national colours might be a way to direct this discussion more towards the national, also enabling minorities to join in. But, as the Finnish example of Saana shows, misinterpretations could easily follow.

The emergence of collaboration or rather co-creation marks crossing of another line. For centuries, the dream of possessing land has been one of the drivers of Estonian nationalism; landscapes, however, are about stewardship. The Soviet layer often meant that collective belonged to nobody, everyone cared about the little piece of land they used. Private property was restored in early 1900s, and by now the self-confidence of people has grown enough to enable wider view. Estonian (and Latvian) landscapes are about changing layers - each socio-economic formation has created one - but currently we are going through a more stable period meaning that people do not need to cope with large landscape changes, but have time to think and discuss future practices.

Finally it is relevant to ask what about the project-based nature of landscape discussion? How will the collected stories and photos be stored and who and when will get access to this? In Finland, the collective data was removed from the Internet; in Estonia not all gathered material is publicly accessible. National landscapes and treasures were selected - what will be the followup of these projects? How fragmented are in fact the everyday landscapes - not the ones 'out there', but the ones studied in project reports, stored in data bases, fixed in documents? These are questions that need to be studied in the future.

So, landscapes are still conservative and repetitive, still about the ideology of harmony of human and nature living together, and not too many new ideas have been introduced during the celebrations. Landscapes still tend to be visual, but with hints of collected stories. Much of the visual in landscape is professionally presented - drone video seems to be the current champion of human scale, as satellite imagery and aerial photos are less palatable. Very often landscapes are of abstract generic nature, natural scenic views, beautiful panoramas, ethnoscape. That past, especially the rural or the agrarian, was the golden age - however, past is a foreign country, as David Lowenthal titled one of his books. The tradition, especially the one that includes the agrarian and mostly omits the urban and/or the industrial, is still important.

In all countries, the celebrations were coordinated by state authorities, but nevertheless, public participation and collaboration was (at least to a certain degree) welcomed. That illustrates that landscapes, in whichever way they are defined, include tensions, both temporal and spatial, not speaking of social and political. The scale of representation is skewed and managed from national to the regional, local and personal. Finally, identity and nation-building are always on the background.

\section{Conclusions}

All in all, Finland's, Estonia's and Latvia's centenaries did confirm dominant landscape narratives. Collective historical commemoration in landscape has been most discussed in Finland, which has enjoyed uninterrupted independence acknowledging Sámi culture and traumatic trace and political tension that followed the Civil, Winter and Continuation wars. Estonian and Latvian cases did not present any major questions of conflict, both are more prone towards the 'golden age' of 
the 'mature' age of first independence period, largely neglecting WWII and Soviet landscape layer. It seems that landscape was in the forefront in Estonia in 2000s, in Latvia, it is highlighted in 2010s. Yet, as far as hindsight goes, cracks emerged that allowed alternative landscapes to appear, although no major innovations took place, for Estonian and Latvian case the approval of regional and some minorities' identities incorporation to the national identity framework.

Owen J. Dwyer and Derek H. Alderman (2008: 166) suggest a three-dimensional framework for analyzing memorial landscapes. "The "text" metaphor emphasizes a critical reading of the histories and ideologies given voice and silenced in the content and form of memorials as well as the dynamic nature of (re)inscribing memory into space. The "arena" metaphor focuses on the capacity of memorials to serve as sites for social groups to actively debate the meaning of history and compete for control over the commemorative process as part of larger struggles over identity. The "performance" metaphor recognizes the important role that bodily enactments, commemorative rituals, and cultural displays occupy in constituting and bringing meaning to memorials, suggesting that the body itself is a site of memory.'

We agree that landscapes are not memorials per se even when studied in national context. However, the metaphors presented by Dwyer and Alderman help to analyze the ways of using and signifying landscapes in centennial festivities. Firstly, we claim that the landscapes functioned as texts that emphasized the historicity or symbolically constructed agelessness of the nation states, and that inevitably renewed the legitimacy of the national readings of the states. In doing so, they, however, presented an unproblematic narrative, sterilized from counter-narratives and narrated with a convivial tone. Landscapes were thus used for manifesting the hegemonic national memory that was collectivized through the idea of participation and togetherness.

Secondly, partly linked to the previous notion, landscapes were indeed used as an arena that enticed people to share their personal landscapes in national context or visit nationally valuable landscape attractions. Participatory methods were used in each country, but at the same time the contexts of the events were organized by public institutions that also affected the selection of the ways in which the anniversaries were praised. Thus the discussion was seemingly open, but the participatory methods rather legitimized the hegemonic ways of nationalizing the landscapes than questioned the national framework, promoted multivocality or presented landscapes as arenas through which the collective traumas could be openly discussed.

Finally, the relationship between individual bodies and landscapes remained somewhat unclear. On the other hand, landscapes were not only represented visually. Instead, people's personal and bodily experiences were utilized both in event that happened in landscapes and were thus multisensory and in competitions that asked people to introduce their 'own' landscapes. Once again, however, these procedures did not open landscapes for a critical discussion, but rather turned people's bodies into sites of memory, just like Dwyer and Alderman suggest. As Simona Mitroiu (2014: 884) points out, "personal lieux de mémoire are not limited to the individual but are shared by a community and because these memories can be transferred from the individual to a collective identity, they in fact help to sustain it'. This seemed to be the case with the centennial landscapes.

That landscapes are handled differently is obvious also from this paper. The approaches between countries differ, due to differences in language, historical backgrounds, but also professional backgrounds of the writers. Finland and Estonia share similar language. Moreover, they share the common origin of landscape research, as both rely heavily on the works of J.G. Granö, Professor of geography first in Tartu, Estonia (1919-1922) and later in Helsinki (1923-1926, 1945-1955) and Turku (1926-1945), Finland. Latvia and Estonia share the tradition of Soviet landscape science that defined the research approach and topics from 1940s onwards. These differences - linguistic, historical, professional - dictate the relation of the cultural and the natural in landscape discourse and also practice.

Landscape is indeed a recorder of our past that stores, layer after layer, traces of our activities. In festive times, the most valuable of this is taken out and re-presented. Of course, what is valued may change in time. The current celebrations allowed for an inventory of the past to be made, a sort of selecting and representing the list of the greatest hits, to borrow from pop culture. This valuation, as we see, is necessary for a better understanding of the past. 
Lotman (2009) has explained how important it is that after turbulent times - cultural explosions, as he calls them - the change is described by the culture, as well as the time before the change. It is important to create the link with what was there before the explosion. If a culture is able to describe the explosion, the pre-explosion becomes part of the culture, if not, the link is lost. Celebrations, such as the centenary of a country, is a perfect occasion to reiterate those links.

After all, the point here is not to get stuck in the past. As the cultural psychologist Valsiner (2018) argues, one should not live off the past, but towards the future.

\section{Acknowledgements}

The Estonian part of the research has been supported by the Estonian Research Agency grant PRG398.

References

[1] Anderson, B. (1983). Imagined Communities. Reflections on the Origin and Spread of Nationalism. London: Verso.

[2] Appleton, J. (1996). The Experience of Landscape. New York: Wiley.

[3] Baker, A. R. H. (1968). A note on the retrogressive and retrospective approaches in historical geography. Erdkunde - Archive for Scientific Geography 22(3), 244-245. DOI: 10.3112/erdkunde.1968.03.07.

[4] Billig, M. (1995). Banal Nationalism. London: Sage.

[5] Brockmeier, J. (2010). After the archive: remapping memory. Culture \& Psychology 16(1), 5-35. DOI: 10.1177/1354067X09353212.

[6] Bunkše, E. V. (1999). Reality of rural landscape symbolism in the formation of a Post-Soviet, Postmodern Latvian identity. Norsk Geografisk Tidsskrift 53, 121-138. DOI: 10.1080/00291959950136849.

[7] Bunkše, E. V. (2001). The case of the missing sublime in Latvian landscape aesthetics and ethics. Ethics, Place and Environment 4(3), 235-245. DOI: 10.1080/13668790120106343.

[8] Burke, P. (1989). History as social memory. In Butler, T. ed., Memory: History, Culture and the Mind (pp. 97-113). Oxford: Basil Blackwell.

[9] Cosgrove, D. (1998). Cultural landscapes. In Unwin, T. ed., European Geography (pp. 6581). London: Longman.

[10] Cosgrove, D. (2008). Geography \& Vision. London: I. B. Tauris.

[11] Daniels, S. (1993). Fields of Vision. Landscape imagery and national identity in England and the United States. Cambridge: Polity Press.

[12] Cubitt, G. (1998). Introduction. In Cubitt, G., ed, Imagining Nations. Manchester: Manchester and New York, 1-21.

[13] Dwyer, O. J. \& Alderman, D. H. (2008). Memorial landscapes: analytic questions and metaphors. GeoJournal 73: 165-178. DOI: 10.1007/s10708-008-9201-5.

[14] Halbwachs, M. (1950). La mémoire collective. Paris: Presses Universitaires de France.

[15] Herb, G. H. (2004). Double vision: territorial strategies in the construction of national identities in Germany, 1949-1979. Annals of the Association of American Geographers 94(1), 140 164. DOI: 10.1111/j.1467-8306.2004.09401008.x.

[16] Häyrynen, M. (2005). Kuvitettu maa. Suomen kansallisen maisemakuvaston rakentuminen. Helsinki: SKS. 
[17] Häyrynen, M. (2008). A kaleidoscopic nation. The Finnish national landscape imagery. In Jones, M. \& Olwig, K. R., eds., Nordic Landscopes. Region and Belonging on the Northern Edge of Europe (pp. 483-510). Minneapolis: University of Minnesota Press.

[18] Häyrynen, M. (2014). Lost Landscapes - Degraded Landscapes as Anti-Landscape. In Nye, D. \& Elkind, S., eds, The Anti-Landscape. Amsterdam \& New York: Rodopi, 147-156. Peltonen, Matti (2000). Between landscape and language: The Finnish national self-image in transition. Scandinavian Journal of History 25(4), 265-280.

[19] Hooson, D., ed. (1994). Geography and National Identity. Oxford: Blackwell.

[20] Ingold, T. (2000). The perception of the environment. Essays on livelihood, dwelling and skill. London: Routledge.

[21] Jokela, S. \& Linkola, H. (2013). "State idea" in the photographs of geography and tourism in Finland in the 1920s. National Identities 15(3), 257-275. DOI: $10.1080 / 14608944.2013 .779644$.

[22] Kaufmann, E. \& Zimmer, O. (1998). In search of the authentic nation: landscape and national identity in Canada and Switzerland. Nations and Nationalism 4(4), 483-510. DOI: 10.1111/j.1354-5078.1998.00483.x.

[23] Käyhkö, N., Granö, O. \& Häyrynen, M. (2004). Finnish landscape studies - a mixture of traditions and recent trends in the analysis of nature-human interactions. Be/Geo 2-3, 245256. DOI: $10.4000 /$ belgeo.13676.

[24] Lindhjem, H., Reinvang, R. \& Zandersen, M. (2015). Landscape Experiences as a Cultural Ecosystem Service in a Nordic Context. Concepts, Values and Decision-making. Copenhagen: Nordic Council of Ministers. DOI: 10.6027/TN2015-549.

[25] Lotman, J. (2009). Culture and Explosion. Cobley, P. \& Grishakova, M., eds., Clark, W., transl. Semiotics, Communication and Cognition 1. Berlin: Mouton de Gruyter.

[26] Lowenthal, D. (1985). The Past is a Foreign Country. Cambridge: Cambridge University Press.

[27] Meinig, D. (1979). The Interpretation of Ordinary Landscapes: Geographical Essays. New York: Oxford University Press.

[28] Mels, T. (2003). Landscape unmasked: Kenneth Olwig and the ghostly relations between concepts. Cultural Geographies 10(3), 379-387. DOI: 10.1191/1474474003eu281 ra.

[29] Mitroiu, S. (2014). Narrative identity and trauma: Sebald's memory landscape. The European Legacy. Toward New Paradigms 19(7), 883-900. DOI: 10.1080/10848770.2014.965525.

[30] Nogué, J. \& Vicente, J. (2004). Landscape and national identity in Catalonia. Political Geography 23(2), 113-132. DOI: 10.1016/j.polgeo.2003.09.005.

[31] Nora, P. (1989). Between memory and history: les lieux de mémoire. Representations 26, 7-24. DOI: 10.2307/2928520.

[32] Paasi, A. (1996). Territories, Boundaries and Consciousness. New York: John Wiley \& Sons.

[33] Paasi, A. (2008). Finnish landscape as social practice: mapping identity and scale. In Jones, M. \& Olwig, K. R., eds., Nordic Landscopes. Region and Belonging on the Northern Edge of Europe (pp. 511-539). Minneapolis: University of Minnesota Press.

[34] Palang, H., Printsmann, A., Konkoly Gyuró, É., Urbanc, M., Skowronek, E. \& Woloszyn, W. (2006). The forgotten rural landscapes of Central and Eastern Europe. Landscape Ecology 21(3), 347-357. DOI: 10.1007/s10980-004-4313-x.

[35] Palang, H. (2010). Time boundaries and landscape change: collective farms 1947-1994. European Countryside 2(3), 169-181. DOI: 10.2478/v10091-010-0012-6.

[36] Palang, H., Alumäe, H., Printsmann, A., Rehema, M., Sepp, K. \& Sooväli-Sepping, H. (2011). Social landscape: ten years of planning valuable landscapes in Estonia. Land Use Policy 28(1), 19-25. DOI: 10.1016/j.landusepol.2010.04.004. 
[37] Palin, T. (1999). Picturing nation. The Finnish landscape and the Finnish people. In Lehtonen, T. M. S. ed., Europe's Northern Frontier (pp. 208-235). Jyväskylä: PS-kustannus.

[38] Parrot, A. (2002). The Baltic States from 1914 to 1923: The First World War and the Wars of Independence. Baltic Defence Review 8(2), 131-158.

[39] Peil, T., Sooväli, H., Palang, H., Oja, T. \& Mander, Ü. (2004). Estonian landscape study: contextual history. BelGeo 2-3, 231-244. DOI: 10.4000/belgeo.13637.

[40] Raento, P. \& Brunn, S. D. (2008). Picturing a nation: Finland in postage stamps, 1917-2000. National Identities 10(1), 49-75. DOI: 10.1080/14608940701819777.

[41] Raivo, P. (2004). Karelia lost or won - materialization of a landscape of contested and commemorated memory. Fennia 182:1, 61-72.

[42] Renan, Ernest (1992). Qu'est-ce qu'une nation? Paris: Presses-Pocket.

[43] Schama, S. (1996). Landscape and Memory. New York: Vintage Books.

[44] Schwartz, K. Z. S. (2006). Nature and national identity after communism: globalizing the ethnoscape. Pittsburgh, PA: University of Pittsburgh Press.

[45] Skultans, V. (2001). Narratives of landscape in Latvian history and memory. Landscape Review 7(2), 25-39.

[46] Smith, A. D. (1991). National Identity. Reno: University of Nevada Press.

[47] Till, K. E. (2004). Political landscapes. In Duncan, J., Johnson, N. \& Schein, R., eds., Companion to Cultural Geography (pp. 347-364). Malden: Blackwell.

[48] Vallius, A. (2013). Kuvien maaseutu: maaseutumaisemakuvaston luomat mielikuvat suomalaisesta maaseutukulttuurista. Jyväskylä: Jyväskylä Studies in Humanities.

[49] Valsiner, J. (2018). Ornamented Lives. Charlotte: IAP.

[50] Vervloet, J. A. J. (1984). Inleiding tot de historische geografie van de Nederlandse cultuurlandschappen. Wageningen: Pudoc.

[51] Zariņa, A. (2010). Path dependency and landscape biographies in Latgale, Latvia: a comparative analysis. European Countryside 2(3), 151-168. DOI: 10.2478/v10091-0100011-7.

[52] Zarina, A. (2013). Path dependence and landscape: initial conditions, contingency and sequences of events in Latgale, Latvia. Geografiska Annaler Series B Human Geography 95(4), 355-373. DOI: 10.1111/geob.12030.

[53] Zarina, A. \& Krumberga, K. (2016). Territoriality of signs: amber in the State's semiotics in Latvia. GeoJournal 83(1), 101-118. DOI: 10.1007/s10708-016-9759-2.

\section{Other sources}

[54] Suomalainen maisema [Finnish Landscape] (2014). Jyväskylä: Docendo.

[55] Suomalainen maisema [Finnish Landscape] (2015). Jyväskylä: Docendo.

[56] Suomalainen maisema [Finnish Landscape] (2016). Jyväskylä: Docendo.

[57] Suomalainen maisema [Finnish Landscape] (2017). Jyväskylä: Docendo. 